\title{
Entrepreneurial Intention Among Nigerian University Students
}

Aliyu Dahiru Muhammad, Ph.D., Bayero University, Nigeria

Sirajo Aliyu, Federal Polytechnic Bauchi, Nigeria

Selim Ahmed, International Islamic University, Malaysia

\begin{abstract}
$^{1}$
Entrepreneurial intention (EI) is one of the major contributing factors to the formation, growth and development of entrepreneurship. It promotes self reliance and brings about initiatives. Entreprenuership on the other hand, has been considered as an engine of growth for economic growth and development of developed and emerging economies. Acadamic discussions and policy initiatives are increasing nowadays on the vital role of entrepreneurial development in a society. This has been buttressed by the recent loss of jobs due to 2008-2009 financial crisis as well as increasing unemloyment across the globe. In Nigeria, the official rate of unemployment is around 24 percent while 46.5 percent of the youth population are unemployed. The unemployed rate among gradutes has increased from 25.6 percent in 2003 to 42.7 percent in 2011. This unwelcome development requires a concerted effort at academic and governmental levels. The objective of this paper is to examine the entreprenuerial intenton among University students in Nigeria. This will help to identify entreprenuerial intention which determines behaviour as well as the need to gauge entrepreneurial awareness among the respondents. The paper uses a modified version of Theory of Planned Behaviour (TPB) as the main framework of examining entrepreneurial intention. A sample size of 205 was drawn from Abubakar Tafawa Balewa Univesity (ATBU). Data was analysed using structural equation modeling. The findings show that, entrepreneurial attitude, subjective norm and power of behavioural control are all significant predictors of EI. In addition, other indirect relationships were also found to be significant. Overall the result shows the model fits the the data well.
\end{abstract}

Keywords: Entrepreneurial Intention; Nigerian University Students; Economic Development; Unemployment

\section{INTRODUCTION}

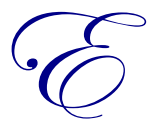

ntrepreneurship has been considered as an engine growth for economic development in the developed, emerging, and developing economies. Thus, it has conquered the cardinal theme of academics and governmental policy makers' interest recently (Muhammad, 2012; Vivarelli, 2012; Kaegon and Nwogu, 2012). Entrepreneurial behavior can be influenced as a result of circumstantial reasons, personal interest, and environmental factors which deem it necessary for a person to be self employed. Aliyu (2013) expatriates the effort of Nigeria in providing various schemes and programs to support entrepreneurship businesses especially through financial incentives. Despite that, a majority of endogenous enterprises failed due to insufficiency of capacity orientation on business being practiced.

Global Entrepreneurship Monitors-GEM (2010:8) Define entrepreneurship education as a process of "building knowledge and skills either "about" or "for the purpose of" entrepreneurship generally, as part of recognized education programs at primary, secondary or tertiary-level educational institutions." Developing entrepreneurial skills among citizenries is one of the major of objectives of the Nigerian vision 20:2020 (National Implementation Plan - NIP, 2010). In the year 2006, entrepreneurship education has been mandated by the government to all Nigerian tertiary institutions and introduced as general studies course in 2007/2008 academic

${ }^{1}$ The paper was presented at International Conference On Islamic Finance, Muamalat, and Financial Criminology, 23-25, October, 2013. 
session (Akhuemonkhan, Raimi and Sofoluwe, 2013). In the same vein, establishing entrepreneurial development centers in those institutions supported the theoretical based in practice. The course was being taught as part of the prerequisite for graduation. Akpan, Effiong, and Ele (2012) noted the aim of adopting entrepreneurship education in the post secondary institutions is to equip graduates to be self reliance and to achieve faster economic development in the country. As a result, some students are doing the course just to have their certificates. Entrepreneurial intention among students is another factor that would influence them to apply the skills after graduation.

Despite the career guidance through entrepreneurial courses and seminars for undergraduates, some of them are taking longer time after graduation before having job. This reflects either the students are not having interest of being self employed or they are having other constraints to become entrepreneurs. To this end, there is need to investigate whether entrepreneurship education is affecting the students' intention to become entrepreneurs after graduation or not. The paper evaluates university students' attitudes, subjective norms, and perceived behavioral control about entrepreneurship intention.

The paper is divided into five sections and begins with introduction. Section two focuses on literature review, model specification and statement of hypotheses. Section three stresses on the methodology adopted on empirical analysis. Results and discussion was presented in section four of the paper and finally section five contains conclusion.

\section{LITERATURE REVIEW}

UNDP (1999:1) considered entrepreneurship development as a "process of enhancing entrepreneurial skills and knowledge through structured training and institution-building programs". The adoption of entrepreneurship education as part of university curriculum would impact on students' capacity building to become self reliance. Thus would tend to accelerates economic growth, development and provide employment opportunities on multiplier effect. In Nigeria, the official rate of unemployment is around 24 percent while 46.5 percent of the youth population are unemployed. The unemployed rate among gradutes has increased from 25.6 percent in 2003 to 42.7 percent in 2011. (National Bureau of Statistics, 2011). This would certainly affect the poverty rate in the country. The real growth attainment can be achieved through alleviating poverty, hunger, unemployment and improving standard of living. Therefore, entrepreneurship development would serve as an avenue in reducing the menace of "underground economic" practices and enhance the well being of the poor.

World bank-IFC (2013) global ranking reported that, Nigeria was rated 131 in providing conducive atmosphere for doing businesses compared with United Kingdom which has been ranked 7 while South Africa and Botswana were scaled 31 and 59 respectively. The global report also positioned Nigeria as 119 compared with 19 of United Kingdom and 53 of South Africa out of 185 countries surveyed on the ease of starting business. This implies the extent in which starting business is highly constrained in Nigeria compared with other listed nations. Global Entrepreneurship Monitors-GEM (2012) conducted a survey and used various indicators to ascertain entrepreneurial attitude, activity and aspirations in Nigeria. Their findings reveal 88 percent of adults (18-64) have perceived capability of starting up business in the future; those with perceived opportunity are 82 percent, entrepreneurial intention stands at 44.3 percent while those with fear of failure are at 21 percent among other indicators. The outcomes pictured in the survey do not interlink attitudinal belief and perceived behavior with subjective norms.

Personal belief and attitude of a person towards setting up new business are regarded as fundamental nascent-factors of entrepreneurship (GEM, 2012). Previous studies on entrepreneurial intention are developed on the Theory of Planned Behaviour (TPB) of Ajzen $(1988,1991)$ and/or that of Shapero and Sokol (1982) on theoretical and model framework (see Izquierdo and Bueleus, 2008; Elfving, Brannback and Carsrud, 2008; Zain, Akram and Ghain, 2010; Mohammed and Aparna, 2011; Thrikawala, 2011; Muhammad, 2012; Ali, Lu and Wang, 2012; Sivarajah and Achchuthan, 2013). Gelderen et, al. (2008:541) noted the similarity between Ajzen's "Perceived behavioural control and attitude" and that of Shapero's "perceived desirability and perceived feasibility" as they are advocating the same concept i.e. "willingness and capability". This research concentrates on TPB to minimize ambiguity and to accept the generality being adopted by scholars. 
Theory of Reasoned Action (Fishbein and Ajzen 1975, 1980) has been extended to Theory of Planned Bahaviour-TBP (Ajzen, 1988, 1991) which asserts that, human behavior is being influenced by three silent beliefs: behavioural beliefs, normative beliefs and control beliefs. In predicting behavioral status, perceived behavior control and behavioral intention can be use directly according to TPB. As a general rule of TPB (Ajzen and Driver, 1991: 188), people's tendencies to perform certain behavior depend on the favorable attitude and subjective norms toward that particular behavior. This implies that, the greater predilection a person has on attitude, subjective norms and perceived behavior control the stronger tendency for him to perform such behavioral act. Ajzen (2006) further explained that, behavioral belief could be favorable or otherwise as a result of attitude toward that behavior. The normative beliefs influences someone behavior due to the subjective norms as usually caused by others' influence (e.g. social group) and control beliefs determined by perceived behavioral control. TPB was found useful in assessing behavioral intention despite the dynamistic nature of human beings in social character. Ajzen (1991:84) proclaimed that TPB is well- matched with Bandura's (1982) "concept of perceived self-efficacy" which is centered on decision for the potential action implementation. The strong influence of people's behavior has usually affected with their perceived behavioral control.

\section{Model Specifications and Hypotheses}

Hypotheses were developed based on the conceptual model of TPB and its variables were also utilized in this study (i.e. Entrepreneurial Intention-EI; Attitude-ATT; Perceived Behavioral Control-PBC and; Subjective Norms-SN).

\section{Entrepreneurial Intention in the Model}

Arbuthnott (2008:154) expatriates the strong effect of intention to behavior as "the more personal and specific our intentions are, the more likely they are to influence our behavior". In this regard, entrepreneurial intention can be determine based on the degree of willingness and ability of individual or group of persons to set up business in future. Entrepreneurial intention serves as dependent variable of the model and it has been used by previous studies (Autio, et.al, 2001; Emmanuel, et. al, 2012; Ali, Lu, and Wang, 2012; Mohammed, 2012; Olakitan, and Ayobami, (2010); Gelrender et, al. 2008; Arbuthnott, 2008). The model interlinks independent variables (Attitude, perceived behavioral control, and subjective norms) with the dependent variable to assess the entrepreneurial intention in one of the Nigerian tertiary institution (Abubakar Tafawa Balewa University-ATBU).

\section{Attitudinal Variables in the Model}

The answers to the rating scale questions had been administered using likert scale of five options. The paper consider the options occurred with the highest frequency, i.e. preference to entrepreneurship as advantageous; having the opportunity, interest, and resources (encouraging aspects), and lack of those variables (discouraging aspects). Based on these attitudinal belief, we hypothesized the importance attached to encouraging variables would strongly relate to the students' intentions of setting up a business after graduation.

Hypothesis 1: Students who select high frequencies on attitudinal preference attributes more intention to become entrepreneurs after graduation.

\section{Perceived Behavioral Control in the Model}

Entrepreneurial self-efficacy, control, creativity and perseverance towards entrepreneurship business after graduation depend on the students' opinion to engage in self-employed works. We hypothesized that those with self-efficacy, perseverance and creativity would be positively related to EI. The literatures ascribed self-efficacy as formulated by Bandura's $(1977,1982)$ concept as the founding root of PBC aspect of Ajzen. Thus, could be regarded as perceived ease or difficulty of an individual to perform a particular behavior (Ajzin, 1991). Previous work by (Ajzen, 2001) considers control behavior as factors that facilitate or obstruct performance of an individual's behavior which is closer to self-efficacy. Gelderen et, al. (2008) added perseverance and control to their research on entrepreneurial intention among university students. 
Hypothesis 2: Students who scale themselves higher in terms of entrepreneurial self-efficacy, control, creativity and perseverance towards entrepreneurship, are more likely to have intentions of starting a business.

\section{Subjective Norms in the Model}

According to TPB individual's opinion could be influenced by social normative pressures due to environmental factors and other relevant belief to perform certain behavior or not. This can also be subjective as result of the inferences influenced by the immediate community (e.g. parents, spouse, friends, religious leaders, and teachers). Mohammed (2012) has proven the importance of subjective norms in students' choice of their career preference. Therefore, students are likely to be self-employed after graduation when their immediate contacts are in support to become entrepreneurs.

Hypothesis 3: Students are likely to have intentions of starting business after graduation if they have positive subjective norms towards their entrepreneurial opinion.

\section{DATA AND METHODOLOGY}

\section{Data}

This study adopted previous questionnaire administered by Muhammad (2012) on entrepreneurial intention among undergraduate of International Islamic University Malaysia (IIUM) with some little modifications. Data were gathered from the survey questionnaires distributed randomly among students on campus at the Abubakar Tafawa Balewa University - ATBU Bauchi, Nigeria in the month of March 2013 (2012/2013 academic session). Samples of 205 valid responses were successfully returned out of 300 questions scripts distributed and are enough for path model analysis (Kline, 2005). The respondents were drawn from various programs/schools of the institution which include: Sciences, Engineering, Management, Education and Environmental studies. The students were sampled at every level their studies, between year one and five with $76.6 \%$ male and $23.4 \%$ female.

\section{Data Analysis Techniques}

Tests for Exploratoy Factor Analysis (EFA)

The value of factor loading indicates the strength of the relationship between the item and the factor. The minimum requirements for the value of factor loading is 0.3; and according to Sharma (1996), factor loading with a value above 0.4 can be regarded as important, while those above 0.5 are considered significant (Sharma, 1996). In this study, varimax, Kaiser-Meyer-Olkin (KMO), and total variance explained used for factor analysis. Based on the varimax rotation, 16 items (statements) constructed into four factors with 64.89 percent of the total variance explained (see Table 1). 
Table 1. Exploratory Factor Analysis (EFA) of Students` Entrepreneurial Intention

\begin{tabular}{|c|c|c|c|c|}
\hline \multirow[t]{2}{*}{ Items } & \multicolumn{4}{|c|}{ Factor loadings } \\
\hline & Factor 1 & Factor 2 & Factor 3 & Factor 4 \\
\hline \multicolumn{5}{|l|}{ Personal Attitude } \\
\hline Being an entrepreneur implies more advantages than disadvantages to me & 0.743 & & & \\
\hline A career as entrepreneur would be attractive to me & 0.790 & & & \\
\hline If I had the opportunity and resources, I would like to start a firm & 0.858 & & & \\
\hline Being an entrepreneur would entail great satisfactions for me & 0.743 & & & \\
\hline \multicolumn{5}{|l|}{\begin{tabular}{|l} 
Subjective Norm \\
\end{tabular}} \\
\hline Your close family & & & 0.638 & \\
\hline Your friends & & & 0.800 & \\
\hline Your colleagues & & & 0.779 & \\
\hline Your religious teachers & & & 0.651 & \\
\hline Your close family & & & 0.638 & \\
\hline \multicolumn{5}{|l|}{$\begin{array}{c}\text { Perceived Behavioural Control } \\
\end{array}$} \\
\hline To start a firm and keep it working would be easy for me & & & & 0.703 \\
\hline I am prepared to start a viable firm & & & & 0.843 \\
\hline I can control the creation process of a new firm & & & & 0.775 \\
\hline I know how to develop an entrepreneurial project & & & & 0.536 \\
\hline I will make every effort to start and run my own firm & & 0.601 & & \\
\hline I am determined to create a firm in the future & & 0.792 & & \\
\hline I have very seriously thought of starting a firm & & 0.789 & & \\
\hline I have the firm intention to start a firm some day & & 0.698 & & \\
\hline Kaiser-Meyer-Olkin (KMO) & \multirow{2}{*}{\multicolumn{4}{|c|}{$\begin{array}{c}0.842 \\
64.89 \%\end{array}$}} \\
\hline Total Variance Explained & & & & \\
\hline
\end{tabular}

The factor analysis results also shows that the minimum factor loading is 0.53 , which is higher than requirement. Moreover, KMO value 0.84 indicates all factor loadings results are acceptable for the further analysis. The result of factor loadings shows the eigenvalues of four factors individually. The highest eigenvalue is 5.82, which has 36.37 percent of variance and the lowest eigenvalue is 1.29 , which has 8.09 percent of the total variance explained.

\section{Tests for Confirmatory Factor Analysis (CFA) and Structural Equation Modeling (SEM)}

According to Kline (2010), the purpose of a measurement model points to the appropriateness as measurement instrument of the observed indicators representing a latent variable. This is echoed by Hair et al. (2010), who observed that in measurement theory, the purpose is to estimate the relationship between the observd and the underlying latent variables. The adequacy of a measurement model is performed by confirmatory factor analysis (CFA); in doing so, four fit indices are checked to ascertain the fitting of the model with the data: chisquare statistic, normed chi-sqaure, root mean square approximation (RMSEA) and comparative fit index (CFI). The model had an adequate fit to the data: chi square per degree of freedom $(13.83 / 5)=2.767$, less than 3 ; CFI $=0.989$, greater than $0.90 ; p=0.017$, less than $\mathrm{p} \geq 0.05$; and RMSEA $=0.090$, less than 0.10 but greater than 0.08 (Hair et al., 2010).

For an adequate model fit, general guidelines suggest cut-off value normed of chi-Square as less than 5; RMSEA value of not more than 0.08 and CFI value above 0.9 (Hair el al., 2010; Byrne, 2010).

Prior to testing the structural equation model, CFA was performed on the entire set of measurement items simultaneously. The process of evaluating the measurement model resulted in deleting terms based on the factor loadings only factor loadings of less than 0.40 (Field, 2009). Based on the CFA tests, all four dimensions had adequate model-to-data fit: normed chi square value below 3.40; CFI value above 0.98 ; and RMSEA value less than 0.10 . This tests also evaluated the reliability and construct validity. Cronbach's Alpha measures the reliability coefficient, which indicates the consistency of the entire scale (Hair, et al., 2010), or the overall reliability of the questionnaire (Field, 2009). The results from this study showed all four dimensions reliability values above 0.70 which indicated that the questionnaire was reliable and consistent (see Table II below). According to Hair et al. (2010), a standardized factor loading should be 0.40 or higher, ideally 0.70 or higher, provides strong evidence of 
convergent validity. In this study, all the items had significant factor loadings, most of them greater than 0.60 , which indicates adequate convergent validity.

Table 2. Construct Validity of Confirmatory Factory Analysis

\begin{tabular}{|c|c|c|}
\hline Items & Stand. loadings & Reliability \\
\hline \multicolumn{3}{|l|}{ Personal Attitude (Normed $\chi^{2}=0.111, C F I=1.00, R M S E A=0.000$ ) } \\
\hline Being an entrepreneur implies more advantages than disadvantages to me & 0.62 & 0.85 \\
\hline A career as entrepreneur would be attractive to me & 0.78 & \\
\hline If I had the opportunity and resources, I would like to start a firm & 0.84 & \\
\hline Being an entrepreneur would entail great satisfactions for me & 0.75 & \\
\hline \multicolumn{3}{|l|}{ Subjective Norm (Normed $\chi^{2}=3.40, C F I=0.989$, RMSEA $=0.109$ ) } \\
\hline Your close family & 0.64 & 0.76 \\
\hline Your friends & 0.94 & \\
\hline Your colleagues & 0.59 & \\
\hline Your religious teachers & 0.41 & \\
\hline \multicolumn{3}{|c|}{ Perceived Behavioural Control (Normed $\chi^{2}=0.822, C F I=1.000, R M S E A=0.000$ ) } \\
\hline To start a firm and keep it working would be easy for me & 0.71 & 0.78 \\
\hline I am prepared to start a viable firm & 0.82 & \\
\hline I can control the creation process of a new firm & 0.73 & \\
\hline I know how to develop an entrepreneurial project & 0.51 & \\
\hline \multicolumn{3}{|c|}{ Entrepreneurial Intention (Normed $\chi^{2}=2.915, C F I=0.993, R M S E A=0.097$ ) } \\
\hline I will make every effort to start and run my own firm & 0.64 & 0.80 \\
\hline I am determined to create a firm in the future & 0.80 & \\
\hline I have very seriously thought of starting a firm & 0.76 & \\
\hline I have the firm intention to start a firm some day & 0.68 & \\
\hline
\end{tabular}

Figure 1. Structural equation modeling of students`entrepreneurial intention

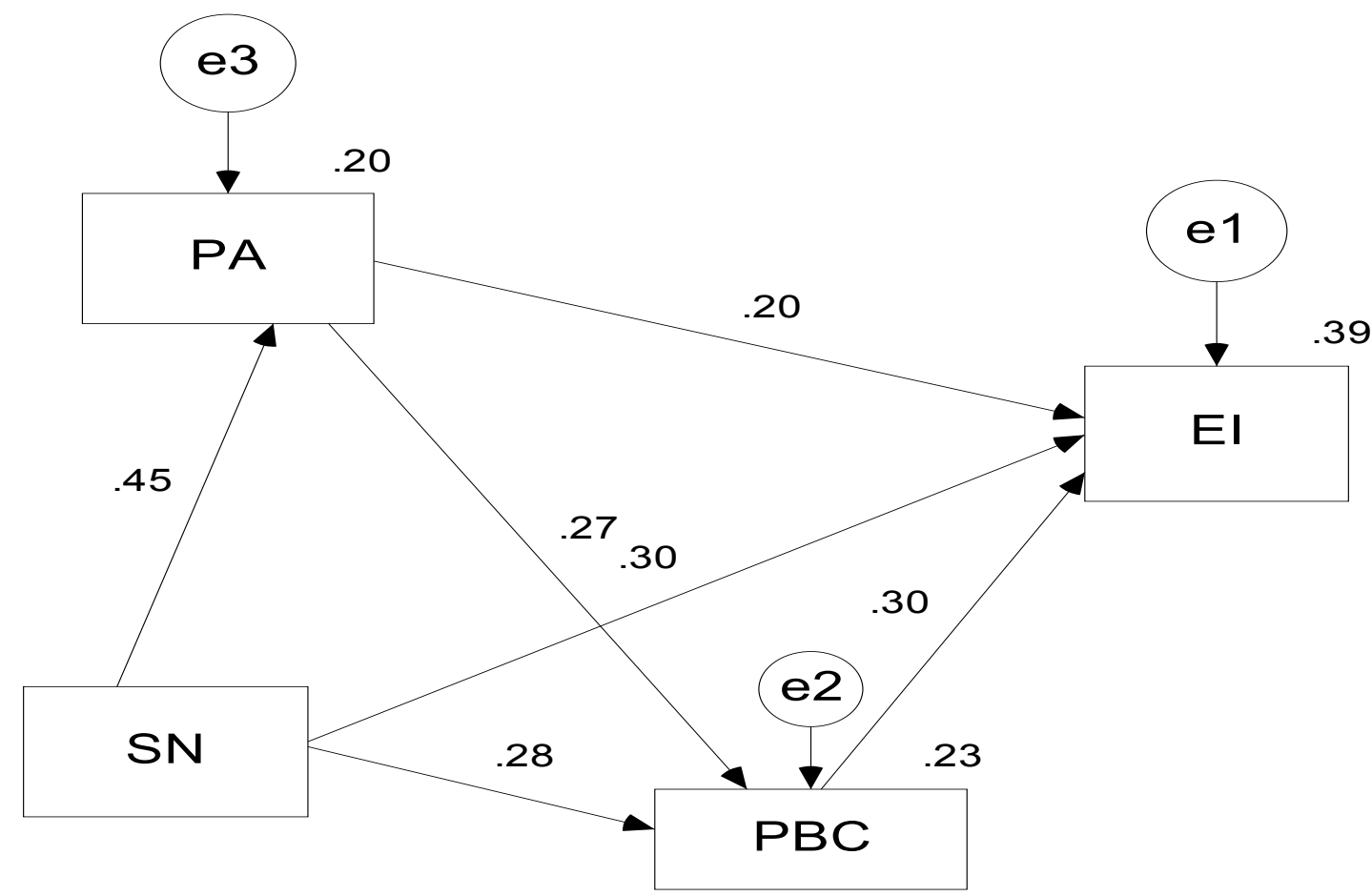

Note: $\mathrm{PA}=$ Personal Attitude; $\mathrm{SN}=$ Subjective Norm; $\mathrm{PBC}=$ Perceived Behavioural Control

$\mathrm{EI}=$ Entrepreneurial Intention

As shown in Figure 1, the R square values for the three dependent (endogenous) variables were entrepreneurial intention $=0.39$, perceived behavioural control $=0.23$ and personal attitude $=0.20$, which indicated that dependent 
(endogenous) variables moderately explained by the independent (exogenous) variables. Moreover, the structural equation modeling results shows that all hypotheses were supported in the SEM model according to the 1\% significant level (see Table III below).

Table 3. Hypothesised Path Coefficients

\begin{tabular}{llccc}
\hline & \multicolumn{1}{c}{ Hypothesized paths } & $\begin{array}{c}\text { Coefficient } \\
(\boldsymbol{\beta})\end{array}$ & $\begin{array}{c}\text { P-value } \\
\text { (sig.) }\end{array}$ & Remarks \\
\hline H1 & Personal Attitude $\rightarrow$ Subjective Norm & 0.449 & 0.001 & Supported \\
H2 & Perceived Behavioural Control $\rightarrow$ Subjective Norm & 0.284 & 0.001 & Supported \\
H3 & Perceived Behavioural Control $\rightarrow$ Personal Attitude & 0.273 & 0.001 & Supported \\
H4 & Entrepreneurial Intention $\rightarrow$ Personal Attitude & 0.195 & 0.002 & Supported \\
H5 & Entrepreneurial Intention $\rightarrow$ Perceived Behavioural Control & 0.303 & 0.001 & Supported \\
H6 & Entrepreneurial Intention $\rightarrow$ Subjective Norm & 0.300 & 0.001 & Supported \\
\hline
\end{tabular}

\section{CONCLUSION}

Entreprenuerial intention is one of the major contributing factors to the formation, growth, and development of entrepreneurship. Entrepreneurship promotes self reliance and brings about initiatives. Entreprenuership has also been considered as an engine of growth for economic growth and development of developed and emerging economies. Acadamic discussions and policy initiatives are increasing nowadays on the vital role of entrepreneurial development in a society. This has been buttressed by the recent loss of jobs due to 2008-2009 financial crisis as well as increasing unemployment across the globe. Using the data from ATBU, and employing structural equation modeling for the analysis, it was found that, entrepreneurial attitude, subjective norm and power of behavioural control are all significant predictors of EI. Overall the result shows the model fits the data well, which has significant implications for policy makers and other stakeholders that wanted to enhance entrepreneurial ability among University students in Nigeria. The determinining factors therefore such as attitude and subjective norms should receive attention since they affect, directly entreprenuerial intention of the repsondents. Furthermore, entreprenerial education and training need to be enhanced further to increase awareness and change the mind-set of the respondents toward imbibing enterepreneurial culture and reduce over reliance on government and other formal sectors. The paper recommends that further research should be conducted at other Nigerian institutions in order to test the results robustness (Gelderen et, al. 2008). Cross sectional research between Universities and other higher institutions would equally portray the real outcome of the Nigerians' behavioural intention towards entrepreneurship.

\section{AUTHOR INFORMATION}

Aliyu Dahiru Muhammad, Ph.D, teaches at the International Institute of Islamic Banking and Finance, Bayero University, P.M.B. 3011, Kano, Nigeria. Phone: +2348180380028, Email: admuhammad.iiibfbuk@buk.edu.ng; alitahir797@yahoo.com. (Contact author)

Sirajo Aliyu, teaches in the Department of Banking and Finance at Federal Polytechnic Bauchi, Gwallameji Village, Off Dass Road, Bauchi-Tafawa Balewa, Bauchi 0231, Nigeria.

Selim Ahmed, in the Department of Business Administration at the International Islamic University in Malaysia.

\section{REFERENCES}

Ajzen, I. \& Fishbein, M. (1980). Understanding attitudes and predicting social behavior. Englewood Cliffs, N.J., $1980)$.

Ajzen, I. (1988). Attitudes, personality, and behavior. Chicago: Dorsey Press.

Ajzen, I. (1991). Theory of planned behaviour. Organizational Behaviour and Human Decision Processes, 50, 179211.

Ajzen, I. (2001): "Nature and operation of attitudes", Annual Review of Psychology, 52, 27-58.

Ajzen, I. (2006). Constructing a Theory of Planned Behavior Questionnaire: Brief Description of the Theory of Planned Behavior; http://people.umass.edu/ajzen/pdf/tpb.questionnaire.pdf Accessed 22 June 2013. 
Ajzen, I. and Driver, B. L. (1991). Prediction of Leisure Participation from Behavioural, Normative, and Control Beliefs: An Application of the Theory of Planned Behaviour: Leisure Science UK Press Vol. 13 PP185-204

Ajzen, I., \& Fishbein, M. (1980). Understanding attitudes and predicting social behavior. Englewood Cliffs, NJ: Prentice-Hall.

Akhuemonkhan, I. A. Raimi, L. and Sofoluwe, A. O (2013). Entrepreneurship Education and Employment Stimulation in Nigeria: Afro Asian Journal of Social Sciences Volume 4, No. 4.1 Quarter I 2013; ISSN: $2229-5313$

Akpan, I. E. Effiong, A. S. and Ele, A. A. (2012). Entrepreneurship Education Policy: An Intervention Strategy for Economic Development in Nigeria; Business \& Entrepreneurship Journal, vol.1, no.1, 2012, 101-110

Ali, S. Lu, W. and Wang, W. (2012). Determinants of Entrepreneurial Intentions among the College Students in: China and Pakistan: Journal of Education and Practice; Vol 3, No 11, 2012

Aliyu, S. (2013). Sustainable Islamic Banking: A Nigeria Sine Quo non to Small and medium enterprises financing: Paper presented at the $2^{\text {nd }}$ International Conference on Islamic Economics and Economies of the OIC Countries (ICIE 2013), Kuala Lumpur, Malaysia.

Arbuthnott, D. K. (2008). Education for sustainable development beyond attitude change: International Journal of Sustainability in Higher Education ;Vol. 10 No. 2, 2009 pp. 152-163

Autio, E. Keeley, H. R. Klofsten, M. Parker, G. G. C. and Hay, M. (2001). Entrepreneurial Intent among Students in Scandinavia and in the USA: Enterprise and Innovation Management Studies, Vol. 2, No. 2, 2001, 145160

Bandura, A. (1977). Self-efficacy: Toward a unifying theory of behavioral change. Psychological Review, 84, 191.215.

Bandura, A. (1982). Self-efficacy mechanism in human agency. American Psychologist, 37, 122-147.

Byrne, B.M. (2010). Structural equation modeling with AMOS: Basic concepts, application, and programming. Second Edition: New York: Routledge.

Elfving, J. Brännback, M. and Carsrud, A. (2009). Understanding the Entrepreneurial Mind (Eds.) : Toward A Contextual Model of Entrepreneurial Intentions; Springer Science and Business Media, LLC 2009 PP 2333

Emmanuel, S. O. Adejoke1, B. K. Olugbenga, O. V. and Olatunde, L. O. (2012). Entrepreneurial Intention among Business and Counseling Students in Lagos State University Sandwich Programme: Journal of Education and Practice: Vol 3, No 14, 2012

Field, A. (2009). Discovering statistics using SPSS. Third Edition, London: SAGE Publications Ltd.

Fishbein, M. \& Ajzen, I. (1980). Implementing Attitudes Psychology and Predicting Social Behavior. Prentice Hall: Englewoods Cliffs.

Fishbein, M. and Ajzen, I. (1975), Belief, Attitude, Intention and Behavior: An Introduction to Theory and Research, Reading, MA: Addison-Wesley.

Gelderen, M., Brand, M., Praag, M., Bodewes, W., Poutsma, E., \& Vangils, A. (2008). Explaning Entrepreneurial Intentions by Means of the Theory of Planned Behavior: Research Working Papers Series, 2, 1-33.

Gelderen, M.V., Brand, M., Praag M.V. Bodewas, W., Poutsma, E. Gils, A. V. (2008).Explaining entrepreneurial intentions by means of the theory of plan behaviour. Career Development International, vol. 13. No.6, pp 538-559.

Global Entrepreneurship Monitor-GEM (2010). Global Entrepreneurship Monitor Special Report: Perspective on Entrepreneurship Education and Training PP.8

Global Entrepreneurship Monitor-GEM (2012). 2012 Global Survey Report: GEM

Hair, J.F., Black, W.C., Babin, B.J. \& Anderson, R.E. (2010). Multivariate data analysis: A global perspective. $7^{\text {th }}$ edition, New Jersey: Pearson Prentice Hall.

Izquierdo, E. Buelens, M. (2008). Competing Models of Entrepreneurial Intentions: The Influence of Entrepreneurial Self-Efficacy and Attitudes: Presentado en Internationalizing Entrepreneurship Education and Training, IntEnt2008 Conference, 17-20 Julio 2008, Oxford, Ohio, USA.

Kaegon L.E.S. and Nwogu U. J. (2012). Entrepreneurship Education in Nigerian Universities: A Panacea for Unemployment in Nigeria: British Journal ofAdvance Academic Research; Volume 1 Number 1 (2012) pp. $57-67$

Kline, R. B. (2005). Principles and Practice of Structural Equation Modelling, $2^{\text {nd }}$ edition, New York: Guildford. Kline, R.B. (2011). Principles and practice of structural equation modeling. $3^{\text {rd }}$ edition, New York: Guilford Press. 
Mohammed, M. and Aparna, M.P. (2011). Entrepreneurial Intentions of MBA Students - A Study in Hyderabad: Entrepreneurial Practice Review; Volume 1 Issue 4 ISSN 1918-1892

Muhammad, D. A. (2012). Entrepreneurial Intention among Undergraduate Students In International Islamic University Malaysia-IIUM: A paper presented at the $6{ }^{\text {th }}$ Islamic Development Management Conference (IDMAC, 2012) Universiti of Sains Malaysia.

National Bureau of Statistics - NBS (2011). Annual Socio-Economic Report: Nigeria Unemployment report 2011.

National Implementation Plan - NIP, (2010). Nigeria Vision 20: 2020 Abridged Version 1st NV20:2020 MediumTerm Implementation Plan $(2010-2013)$

Olakitan, O. O. and Ayobami, P. A. (2010). Entrepreneurial Intentions: A Theoretical Framework: Journal of Management and Corperate Governance : Volume 2, September 2010

Shapero, A., \& Sokol, L. (1982). The social dimensions of entrepreneurship. In C.A. Kent, D.L. Sexton, \& K.H. Vesper (Eds.) Encyclopedia of Entrepreneurship, (pp. 72-89). Englewood Cliffs: Prentice Hall.

Sharma, S. (1996). Applied Multivariate Techniques. New York. John Wiley \& Sons.

Sivarajah, K. and Achchuthan , S. (2013). Entrepreneurial Intention among Undergraduates: Review of Literature: European Journal of Business and Management; Vol.5, No.5, 2013

Thrikawala,S. (2011). The determinants of entrepreneurial intention among acadamics in Srilanka : International conference on economics and finance research, LACSIT press, singapore, 4, 454-458.

United Nations Development Programme- UNDP (2009). Entrepreneurship Development: UNDP; No. 2, December 1999

Vivarelli, M.(2012). Drivers of Entrepreneurship and Post-Entry Performance: Microeconomic Evidence from Advanced and Developing Countries; World Bank Policy Research Working Paper WPS6245

World Bank and International Financial Corporation (2013). Doing Business 2013: Washington, DC

Zain, M. Z. Akram, M. A. and Ghani, K. E. (2010). Entrepreneurship Intention among Malaysian Business Students: Canadian Social Science; Vol. 6, No. 3, 2010, pp. 34-44. 


\section{NOTES}

